\title{
Coastline changes and sedimentation related with the opening of an artificial channel: the Valo Grande Delta, SE Brazil
}

\author{
MICHEL M. DE MAHIQUES ${ }^{1}$, RUBENS C.L. FIGUEIRA ${ }^{1}$, DANIEL P.V. ALVES ${ }^{1}$, \\ DIANA M. ITALIANI ${ }^{1}$, CRISTINA C. MARTINS ${ }^{2}$ and JOÃO M.A. DIAS ${ }^{3}$ \\ ${ }^{1}$ Instituto Oceanográfico, Universidade de São Paulo, Praça do Oceanográfico, 191, 05508-190 São Paulo, SP, Brasil \\ ${ }^{2}$ Fundação de Estudos e Pesquisas Aquáticas/FUNDESPA, Av. Afranio Peixoto, 412, 05507-000 São Paulo, SP, Brasil \\ ${ }^{3}$ Universidade do Algarve, Estrada da Penha, 8005-139 Faro, Portugal
}

Manuscript received on April 29, 2013; accepted for publication on April 25, 2014

\begin{abstract}
The role played by human activity in coastline changes indicates a general tendency of retreating coasts, especially deltaic environments, as a result of the recent trend of sea level rise as well as the blockage of the transfer of sediments towards the coast, especially due to the construction of dams. This is particularly important in deltaic environments which have been suffering a dramatic loss of area in the last decades. In contrast, in this paper, we report the origin and evolution of an anthropogenic delta, the Valo Grande delta, on the south-eastern Brazilian coast, whose origin is related to the opening of an artificial channel and the diversion of the main flow of the Ribeira de Iguape River. The methodology included the analysis of coastline changes, bathymetry and coring, which were used to determine the sedimentation rates and grain-size changes over time. The results allowed us to recognize the different facies of the anthropogenic delta and establish its lateral and vertical depositional trends. Despite not being very frequent, anthropogenic deltas represent a favorable environment for the record of natural and anthropogenic changes in historical times and, thus, deserve more attention from researchers of different subjects.
\end{abstract}

Key words: anthropic activity, Delta, sedimentation, lagoon.

\section{INTRODUCTION}

Over the last few centuries, anthropogenic processes have been acting as major factors modifying the morphology and sedimentary processes of coasts (Syvitski et al. 2005, Syvitski and Milliman 2007, Syvitski and Saito 2007, El Banna and Frihy 2009). The role played by human activity in the modification of coastal sedimentation has been reported in several studies (Antonelli et al. 2004, Jaffe et al. 2007, Simeoni and Corbau 2009, Syvitski et al. 2009).

Correspondence to: Michel Michaelovitch de Mahiques E-mail:mahiques@usp.br
Human activity can result in either erosional processes, usually related to the construction of dams in the upstream (Gao and Wang 2008) and to reforestation (Marchetti 2002) or, to a lesser extent, in accretional phenomena, such as the modification of riverine flows or variations to the uses of lands (Bonachea et al. 2010).

The term "Anthropogenic Delta" was originally (and solely) used by Ren (1992) to report the development of the Abandoned Yellow River Delta (China) as a result of the diversion of the mouth of the Yellow River from the Bohai Sea to 
the Yellow Sea. Nevertheless, this term could be applied at least partially to several other cases in the world, such as the Po River (Italy) (Marchetti 2002) and the Rhone River (France) (Antonelli et al. 2004). An impressive case of an anthropogenic delta development is the feature resulting from the construction of the Canal del Dique, a man-made channel constructed in the $17^{\text {th }}$ century in the Magdalena River (Colombia), which led to the development of an artificial delta. This delta has shown lateral accretions of as high as 100 meters per year (Restrepo and López 2008).

In this sense we understand that the expression "Anthropogenic Delta" must be redeemed and used in those cases in which a deltaic environment can be characterized as being mainly formed (or modified) by human action.

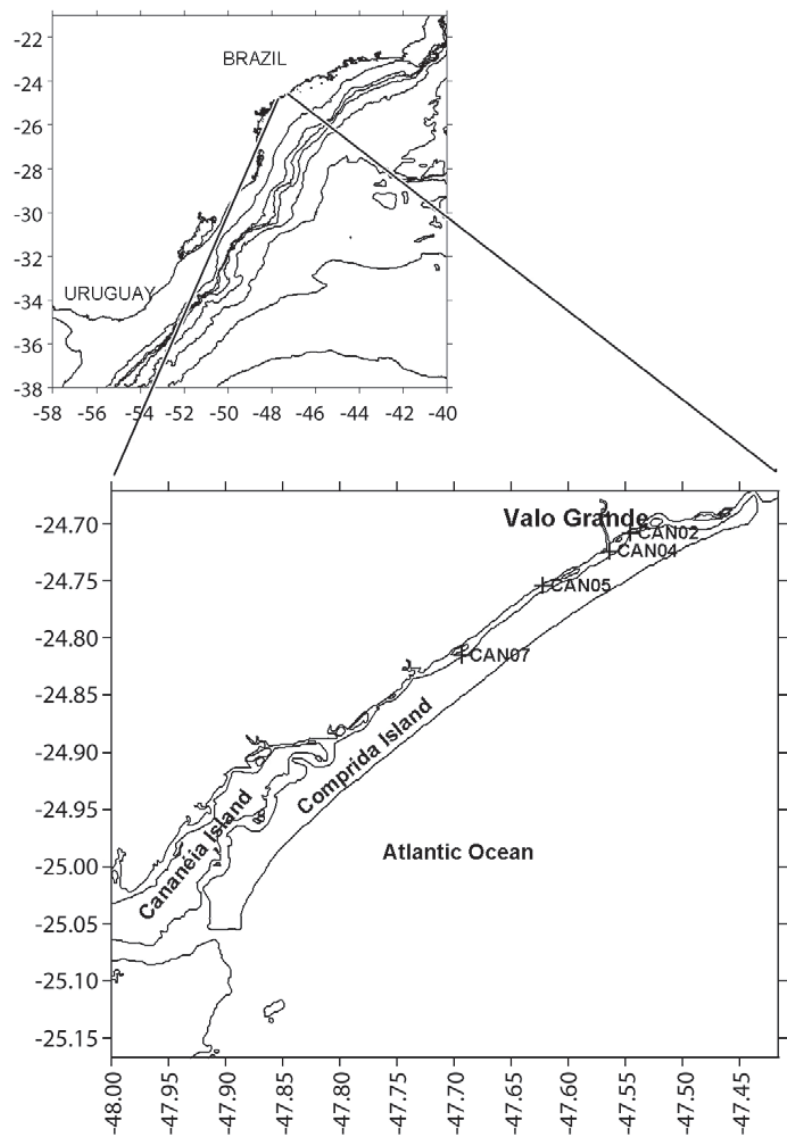

Figure 1 - Location of the study area as well as the cores used in this study.
In this study, we report the development of an intralagoonal anthropogenic delta, the Valo Grande Delta, which resulted from the opening of an artificial channel at the beginning of the $19^{\text {th }}$ century. This channel led to a complete modification of the hydrographic and sedimentary processes in a formerly lagoonal environment, the Cananéia-Iguape system, on the southeastern Brazilian coast (Figure 1).

\section{STUDY AREA}

The Ribeira River forms the largest drainage basin of the S-SE Brazilian coast (from $22^{\circ} \mathrm{S}$ to $30^{\circ} \mathrm{S}$ ), with an area of approximately $25.000 \mathrm{~km}^{2}$. The outflow of the river in its lower course varies from approximately 300 to more than $1.200 \mathrm{~m}^{3} \cdot \mathrm{s}^{-1}$, with the variation in flow being influenced strongly by the subtropical humid climate.

The opening of an artificial channel connecting the Ribeira de Iguape River with the CananéiaIguape system began in 1827 and was finished in 1852. The aim of the opening of this channel was to connect a meander of the river, called Porto do Ribeira (Ribeira Harbor), where the agricultural goods coming from the upstream areas disembarked, to the city of Iguape, located at the margins of the Cananéia-Iguape system, which was at that time one of the most important export harbors of the former Brazilian Empire.

The channel, excavated in friable unconsolidated Late Holocene sands, was rapidly eroded at a rate that reached more than 4 meters per year. The original dimensions (4.4 meters wide and 2 meters deep) of the channel resulted in the current dimensions, with a width of approximately 250 meters and depths of up to 7 meters. The channel's present name, Valo Grande ("Big Scour"), is a reference to the dimensions the channel acquired a few decades after it was opened. As a result of the widening of the channel, approximately $60 \%$ of the river flow and its suspended load were transferred to the lagoonal system, leading to a drastic decrease in the salinity of the coastal system on one side and 
a tremendous siltation phenomenon in the lagoonal system on the other. Finally, the loss of competence of the river in its lowermost sector resulted in its colmatation in such a way that the decision to block the Valo Grande with a dam in 1978 led to catastrophic flooding in the upstream areas during the El Niño years of 1982 and 1983. The dam was partially destroyed by the flood, as well as by the population of Iguape a few months after.

Today, the channel is completely open and erosion of the margins still occurs, causing frequent damage to the city of Iguape. Freshwater salinity values are measured in the city of Cananéia, located approximately $60 \mathrm{~km}$ to the south of the Valo Grande, in the southern sector of the lagoonal system, during heavy rains.

According to the Köppen classification, the climate of the region shows characteristics of a humid tropical climate, varying at the decadal scale from humid tropical without a dry season to humid tropical with a cool summer. The rainfall shows average values of approximately $2200 \mathrm{~mm} . \mathrm{yr}^{-1}$, with a marked rainy season between November and February. The annual average temperatures vary from 16 to $19^{\circ} \mathrm{C}$, but temperatures as low as $0^{\circ} \mathrm{C}$ or as high as $35^{\circ} \mathrm{C}$ have been recorded.

Due to the climatic and geomorphologic characteristics, the vegetation cover is marked by the extensive presence of salt marshes and mangroves on the margins of the lagoonal areas and by dune vegetation of the Atlantic forests on the higher areas. Due to the opening of the artificial channel, mangroves are suffering a dramatic retreat and are being substituted by freshwater vegetation.

\section{MATERIALS AND METHODS}

\section{COASTLINe CHANGES}

The first georeferenced map of the area was published in 1914 (Commissão Geographica e Geológica do Estado de São Paulo 1914), showing the coastline as defined by a survey performed in
1907. Together with this first map, we also used a topographic map, published by the Brazilian Institute of Geography and Statistics (IBGE 1973) (scale 1:50.000), a photogrammetric survey performed in 2001 (scale 1:25.000), and a series of Landsat 5 images from different years (1987 to 2008). All of the images have been georeferenced with the aid of Envi software (Exelis Visual Information Solutions, Boulder, CO, USA).

BATHYMETRIC SURVEY

Approximately $55 \mathrm{~km}$ of echosounding lines were made in February 2008 with the utilization of a Furuno Echosounder equipped with a 200 $\mathrm{kHz}$ transducer. The data were corrected for tidal variation and the speed of sound as well as for the removal of spikes. The data were then used for the elaboration of the bathymetrical map using the krigging interpolator of the Surfer Software package (Golden Software, Golden, CO, USA), version 7.0.

The selected bathymetrical lines inside the Valo Grande were also chosen for a comparison with topographic data obtained in 1891 (when available), 1907 (Commissão Geographica e Geológica 1914), and 2008. Differences in the width and area of the sections between the profiles were calculated with the BMAP software package (Beach Morphology Analysis Package, Coastal Engineering Research Center, Vicksburg, MS), version 2.0.

CORES

Five cores were collected with the aid of a VT1 Rossfelder Vibracorer at selected points following a progressive distance from the mouth of the Valo Grande. Table I and Figure 1 show, respectively, the coordinates and locations of the cores used in this study.

Each core was opened, macroscopically described and sampled continuously at intervals of $2 \mathrm{~cm}$. The samples were immediately frozen for subsequent freeze-drying. 
Determination of the chronology and sedimentation rates was obtained via ${ }^{210} \mathrm{~Pb}$ gamma spectrometry by analyzing its photopeak at $47 \mathrm{keV}$ using a low background Ge detector (EG\&G Ortec model GMX 25190P), as described in Figueira et al. (2007). The calculation of the sedimentation rate based on the unsupported $\mathrm{Pb}$ was made via the $\mathrm{CIC}$ (Concentration Initial Constant) Model (Appleby and Oldfield 1978, Joshi and Shukla 1991). The sedimentation rate was calculated using the formula:

$$
\mathrm{S}=(\lambda . \mathrm{D}) /\left(\operatorname{Ln}\left(\mathrm{C}_{0}{ }^{210} \mathrm{~Pb}\right) /\left(\mathrm{C}^{210} \mathrm{~Pb}\right)\right.
$$

Where $\mathrm{S}$ is the sedimentation rate in $\mathrm{cm} . \mathrm{yr}-1, \lambda$ is the radioactive decay constant of ${ }^{210} \mathrm{~Pb}$ (equal to $0.31076 \mathrm{yr}-1)$, $\mathrm{D}$ is the distance between the coretop and the measured stratum (in cm), $\mathrm{C}_{0}{ }^{210} \mathrm{~Pb}$ is the count of the unsupported ${ }^{210} \mathrm{~Pb}$ at the coretop, and $\mathrm{C}^{210} \mathrm{~Pb}$ is the count of the unsupported ${ }^{210} \mathrm{~Pb}$ at the measured stratum. The reliability of the radiochronological technique was verified by comparison with changes in the foraminiferal record observed in core CAN05 (Mahiques et al. 2009).

GRAIN SIZE

Grain size was determined in decarbonated samples using a Malvern Mastersizer 2000 Laser analyzer. The results are presented using the Particle Size Distribution (PSD) format proposed by Beierle et al. (2002) and Gyllencreutz (2005) with the interpolation procedures used by Gyllencreutz et al. (2010).

TABLE I

Position and length of the cores selected for this study.

\begin{tabular}{c|c|c|c}
\hline CORE & Lat $(\mathbf{S})$ & Long $(\mathbf{W})$ & Length(m) \\
\hline CAN02 & $24^{\circ} 42.477$ & $47^{\circ} 32.787$ & 1.44 \\
\hline CAN04 & $24^{\circ} 43.418$ & $47^{\circ} 33.858$ & 1.50 \\
\hline CAN05 & $24^{\circ} 45.245$ & $47^{\circ} 37.370$ & 2.00 \\
\hline CAN07 & $24^{\circ} 48.895$ & $47^{\circ} 41.612$ & 1.27 \\
\hline CAN15 & $24^{\circ} 43.242$ & $47^{\circ} 33.750$ & 1.31 \\
\hline
\end{tabular}

Figure 2 shows the coastline changes in the selected years. The formation of several islands is evident in the proximity of the Valo Grande mouth throughout the $20^{\text {th }}$ century. Three main archipelagos have been formed since the opening of the Valo Grande, the Iguape Harbor (letter A in Figure 2), Enseada ("Bight", letter B) and Caranguejo ("Crab", letter $\mathrm{C}$ ), with exceptional accretionary processes occurring in the last decade. It is notable that, according to the local population, the mangrove vegetation of the Iguape Harbor archipelago has progressively disappeared in the last 10 years, which is detrimental to freshwater plants. It can also be seen that the Iguape Harbor archipelago is being progressively merged with the original margins, leading to a severe progradation of the coastline.

The present bathymetrical configuration of the area is presented in the Digital Elevation Model shown in Figure 3. Together with the coastline changes, it is possible to observe the configuration of the deltaic plain and front, the latter being located adjacent to the mouth of the Valo Grande and being displaced towards the Ilha Comprida coastline. Two main submerged channels can be observed, each being oriented to one side of the lagoonal complex. Both the Iguape Harbor and the Caranguejo archipelagos represent the construction of the Valo Grande upper deltaic plain. According to local fishermen, it is becoming virtually impossible to navigate towards the south of the lagoonal system due to the intense siltation processes occurring in the Caranguejo area.

A comparison between the widths and areas of the sections of the selected bathymetrical lines inside the Valo Grande is shown in Table II, line A being located upstream and line $G$ being located downstream of the channel. With the exception of line $\mathrm{B}$, which is located close to the dam that was destroyed, all of the lines clearly indicate the expressive widening of the channel at a rate even 

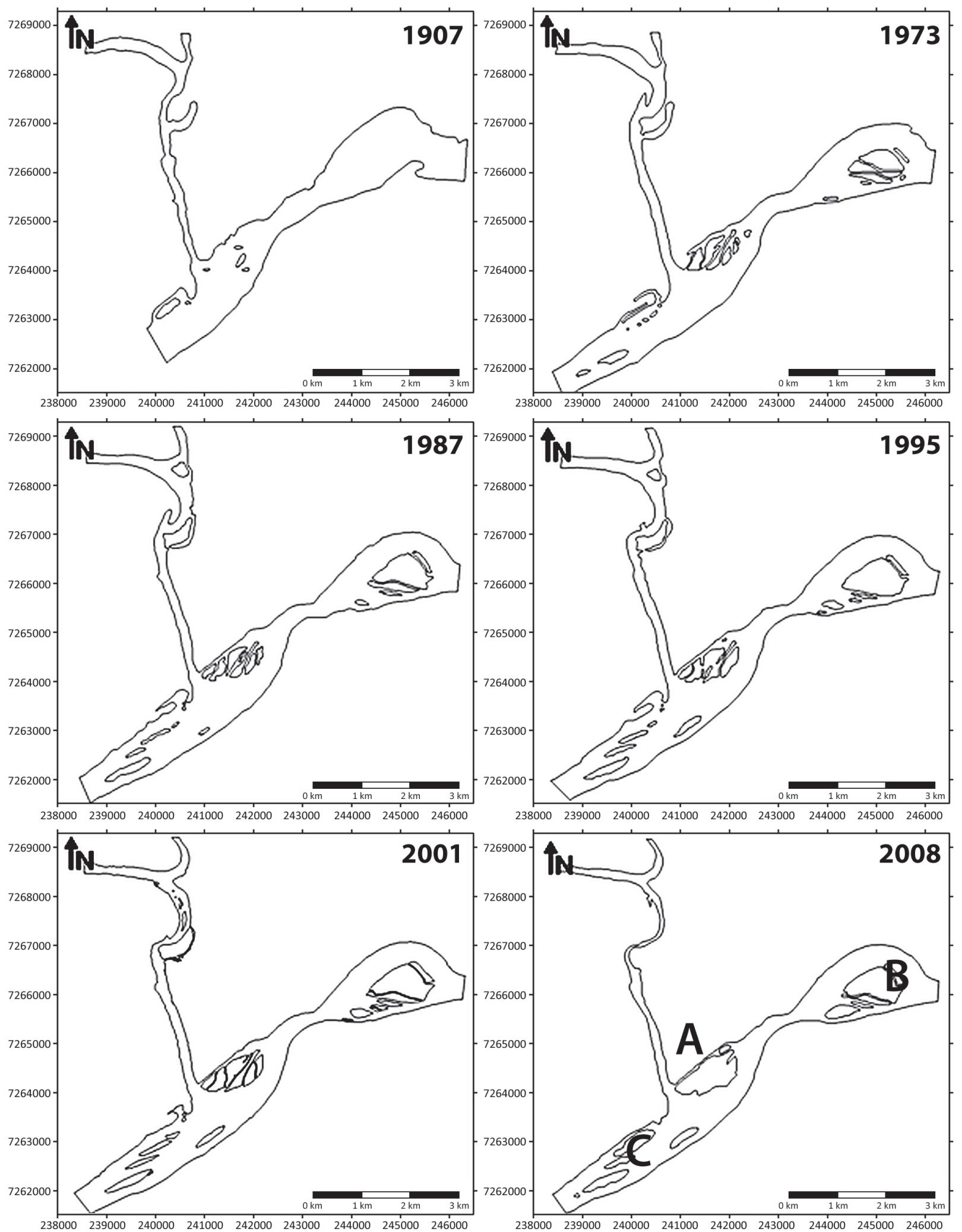

Figure 2 - Coastline configuration of the study area in the years of 1907, 1973, 1987, 1995, 2001 and 2008. Letters A, B and C indicate the location of the Iguape Harbor, Enseada and Caranguejo archipelagos, respectively. Original published in Italiani and Mahiques (2014). 
greater than $50 \%$ over approximately the last 100 years. However, it is also evident that the area of the sections of the lines located closer to the mouth suffered a reduction in area in the same period, indicating that this area is in progressive colmatation, and lateral erosion is expected to continue to maintain the channel flow.

The plots of the ${ }^{210} \mathrm{~Pb}_{\mathrm{xs}}$ activities versus depth are shown in Figure 4, and the particle size distributions (PSD) are shown in Figure 5.

Core CAN04 (150 cm long) is the closest to the mouth of the Valo Grande, and it was collected from a location at its confluence with the CananéiaIguape channel. This core presented an average sedimentation rate of $0.72 \pm 0.01 \mathrm{~cm} \mathrm{yr}^{-1}$, as determined by ${ }^{210} \mathrm{~Pb}$ spectrometry. The PSD shows a conspicuous change in the grain size distribution at $100 \mathrm{~cm}$, corresponding to the year 1900 . The basal sequence is marked by the prevalence of poorly sorted silts, with a grain size mode on coarse silt, the amount of sands and clays being completely subsidiary. Given the grain size characteristics of the basal section, it seems that the place at which the core was collected was not directly affected by the opening of the Valo Grande until the beginning of the $20^{\text {th }}$ century. The upper sequence is characterized by the deposition of sands (fine to very fine sand) with variable amounts of silts. A slight fining upward is observed from $20 \mathrm{~cm}$, corresponding to the middle of the 1980s. The location of the core allows us to recognize this upper sequence as representative of the development of the lower deltaic plain.

Core CAN15 (137 cm long) was collected on the top of the deltaic front. The average sedimentation rate, as determined by ${ }^{210} \mathrm{~Pb}$ spectrometry, is

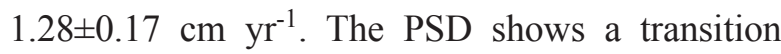
from a basal sequence marked by the presence of silty sands, up to a depth of $60 \mathrm{~cm}$ (1960s), to an

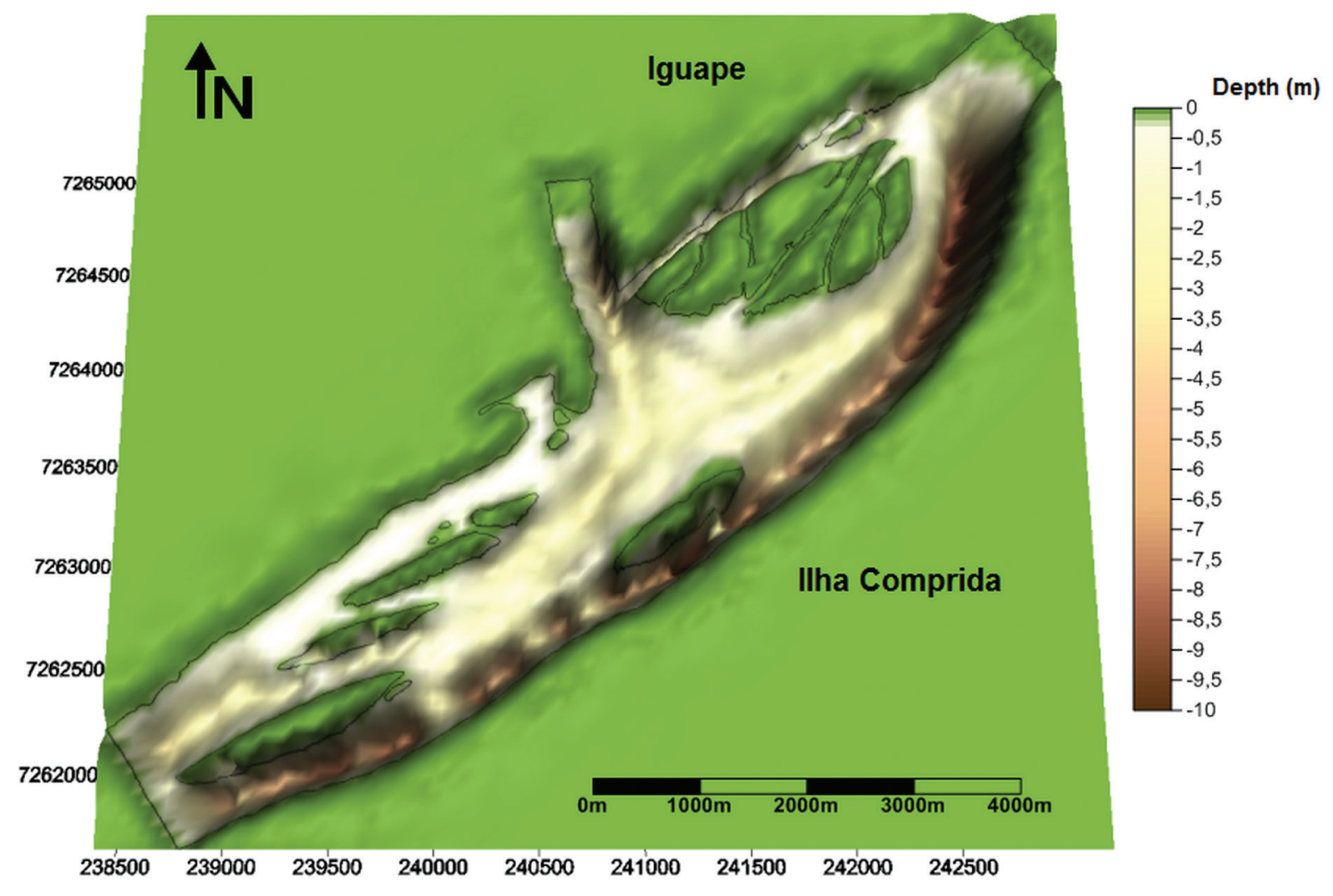

Figure 3 - Digital Elevation Model (DEM) produced from echosounding data obtained in the February 2008 survey. Original published in Italiani and Mahiques (2014). 
TABLE II

Width and area of selected transects in the Valo Grande channel in the years of 1891, 1907 and 2008 ( $A$ is the most upstream and $\mathrm{G}$ is the most downstream). Also, the ratio between width and area between the years of 2008 and 1907 is indicated.

\begin{tabular}{|c|c|c|c|c|c|c|c|c|}
\hline \multirow{2}{*}{$\begin{array}{c}\text { Transect } \\
\text { Year }\end{array}$} & \multicolumn{3}{|c|}{ Width (m) } & \multicolumn{3}{|c|}{ Area $\left(m^{2}\right)$} & \multirow{2}{*}{$\begin{array}{c}\text { \%Width } \\
2008 / 1907\end{array}$} & \multirow{2}{*}{$\begin{array}{c}\text { \%Area } \\
2008 / 1907\end{array}$} \\
\hline & 1891 & 1907 & 2008 & 1891 & 1907 & 2008 & & \\
\hline A & - & 131 & 203 & - & 1304 & 1220 & 55 & -6 \\
\hline B & - & 294 & 207 & - & 2061 & 2118 & -30 & 3 \\
\hline $\mathrm{C}$ & 124 & 168 & 207 & 455.6 & 1125 & 622 & 23 & -45 \\
\hline D & - & 135 & 204 & - & 1221 & 585 & 51 & -52 \\
\hline $\mathrm{E}$ & - & 132 & 195 & - & 1274 & 617 & 48 & -52 \\
\hline $\mathrm{F}$ & - & 149 & 224 & 0 & 1198 & 650 & 50 & -46 \\
\hline G & 144 & 149 & 207 & 683.3 & 1267 & 741 & 39 & -42 \\
\hline
\end{tabular}

upper sequence marked by the prevalence of fine to very fine sands with a smaller contribution of finer fractions. A slight fining upward is observed in the topmost $10 \mathrm{~cm}$ of the core. On the basis of the location of the core, we may assume that it is representative of the deltaic front, the progressive fining upward indicating the trapping of the sandy fraction in a more proximal area of the delta.

Core CAN02 (140 cm long) was sampled approximately $2 \mathrm{~km}$ from the mouth of the Valo Grande channel towards the northernmost mouth of the lagoon (Figure 1). On the basis of the ${ }^{210} \mathrm{~Pb}$ chronology, Core CAN02 exhibited an average sedimentation rate of $1.00 \pm 0.06 \mathrm{~cm} \mathrm{yr}^{-1}$ (Figure 4). As with the previously described cores, core CAN02 shows a similar trend of a silty sand basal sequence separated by a sharp contact ( $80 \mathrm{~cm}$ - with an upper fine to very fine sand sequence). In this core, the topmost fining upward is more evident, being located at $20 \mathrm{~cm}$ (1987). Core CAN02 is representative of the more proximal facies of the subaqueous deltaic plain.

Core CAN05 (168 cm long) was sampled approximately $7.5 \mathrm{~km}$ from the mouth of the Valo Grande. The ${ }^{210} \mathrm{~Pb}$-based age model clearly exhibited two distinct trends of sedimentation rates (Figure 4). From the base of the core to a depth of $70 \mathrm{~cm}$, the gross estimated sedimentation rate was $0.55 \pm 0.04 \mathrm{~cm} \mathrm{yr}^{-1}$ (despite being based on only three samples). From $70 \mathrm{~cm}$ to the top of the core, the average sedimentation rate increased to $1.52 \pm 0.11 \mathrm{~cm} \mathrm{yr}^{-1}$. This core exhibits a PSD that is an inversion of the trend observed in the previous cores. The basal sequence corresponds to moderate to poorly sorted sand with a limited amount of silts concentrated in the base of the core; and an upper sequence separated by a sharp contact located at $130 \mathrm{~cm}(1850 \mathrm{~s})$ approximately marked by the prevalence of silts (coarse silt). It can be assumed that the upper sequence represents the more distal areas of the subaqueous deltaic plain.

Finally, Core CAN07 (125 cm long) was collected approximately $20 \mathrm{~km}$ from the mouth of the Valo Grande. The average sedimentation rate for the core was calculated as $0.67 \pm 0.05 \mathrm{~cm} \mathrm{yr}^{-1}$. The PSD shows a rather homogeneous grain size distribution, with the prevalence of medium to fine sands all along the core. Few inputs of silts are present in the core. We assumed that core CAN07 is out of the direct influence of the development of the delta, and the influence of the Valo Grande discharge seemed to occur very seldom along time, and it is represented especially throughout the pulses of fine sediments.

The development of the so-called Valo Grande delta represents a particular situation in a scenario in which the coastal deltas of tropical to temperate areas are experiencing a general trend of coastline retreat (Guillén and Palanques 1997, Kapsimalis 


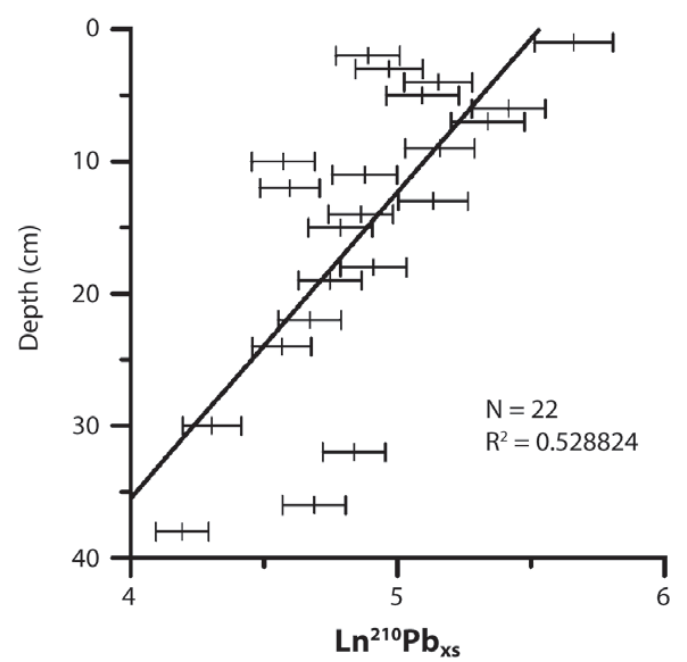

(A) CANO4

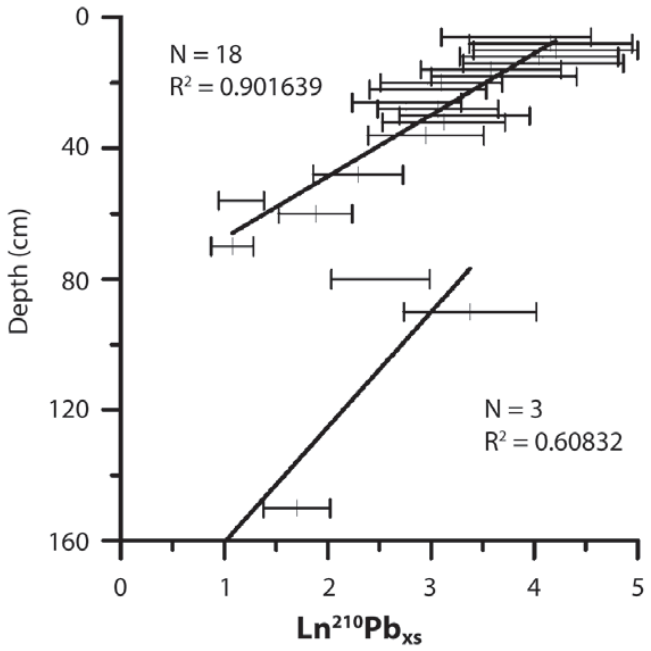

(C) CAN05

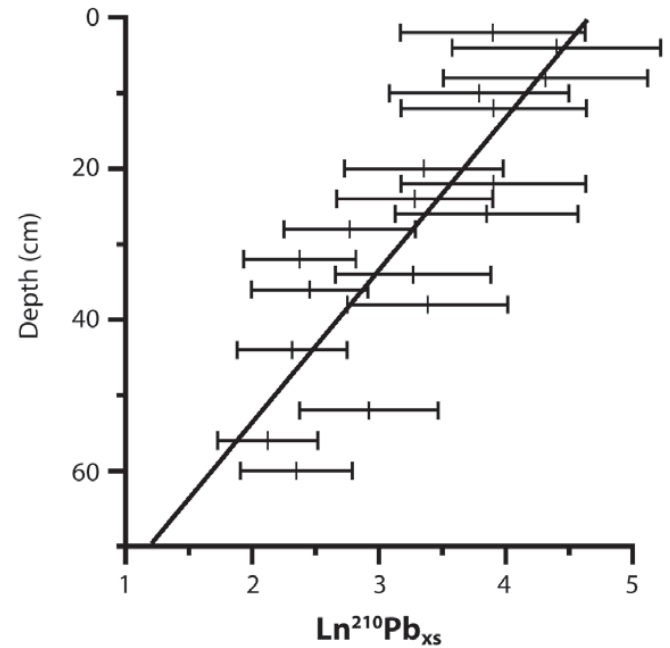

(B) CANO2

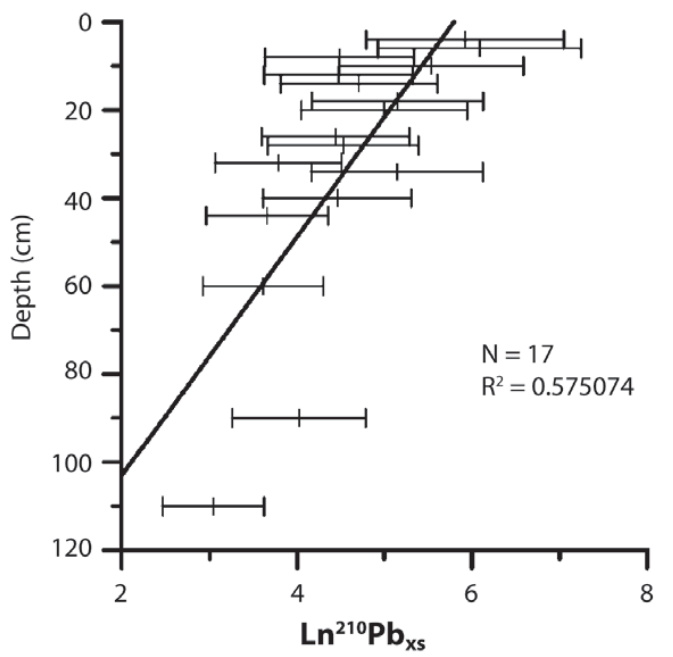

(D) CANO7

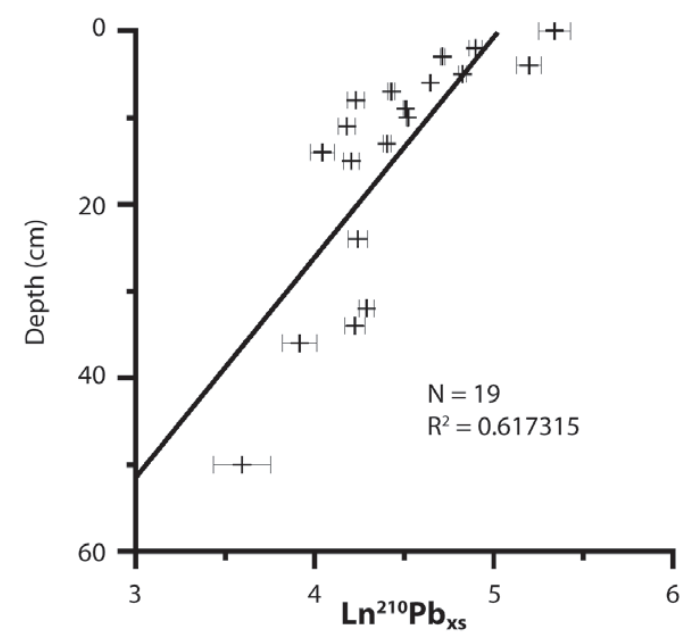

(E) CAN15

Figure 4 - Plot of $\mathrm{Ln}^{210} \mathrm{~Pb}_{\mathrm{xs}}$ activity versus depth in the cores selected for this study. 

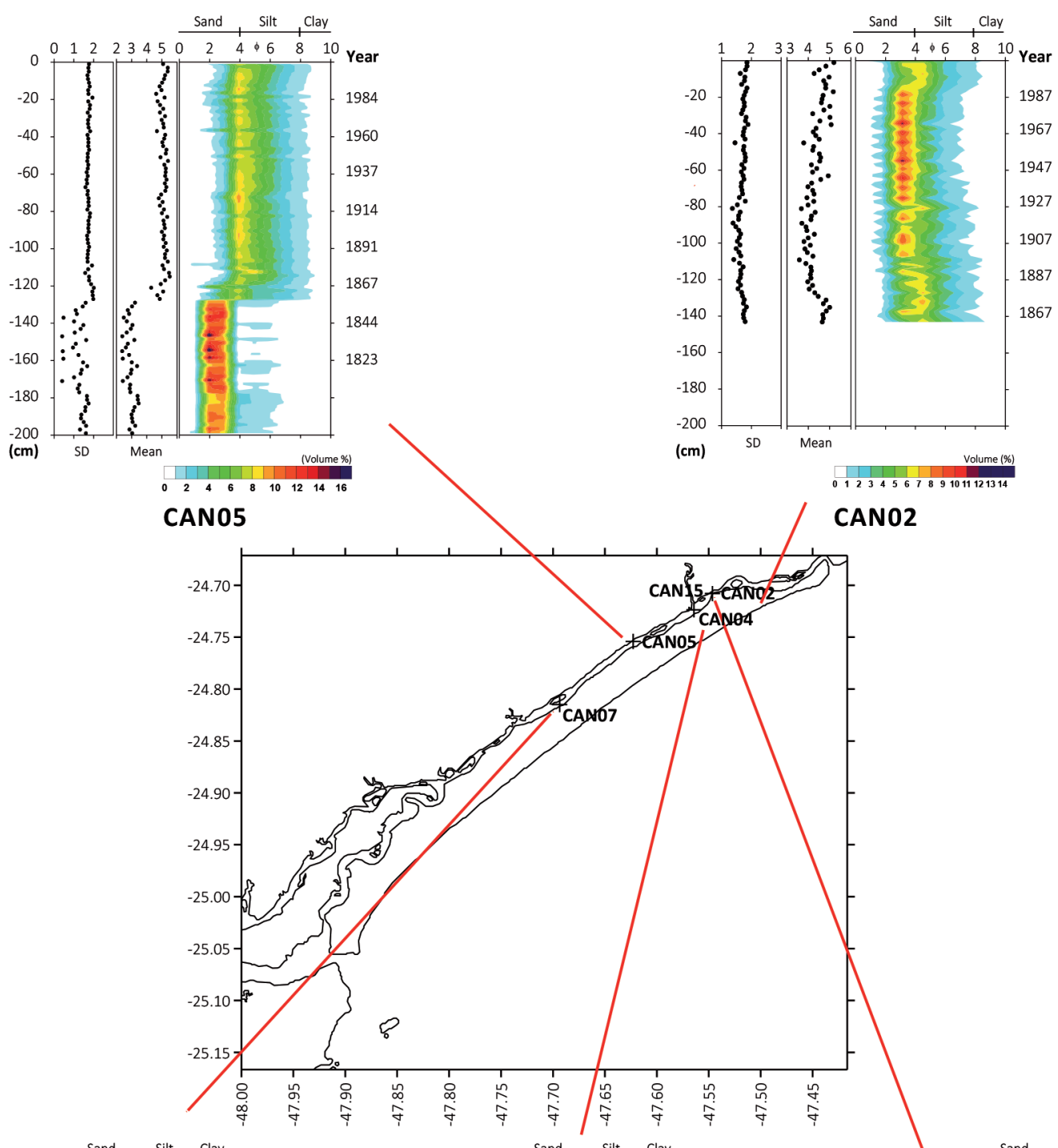

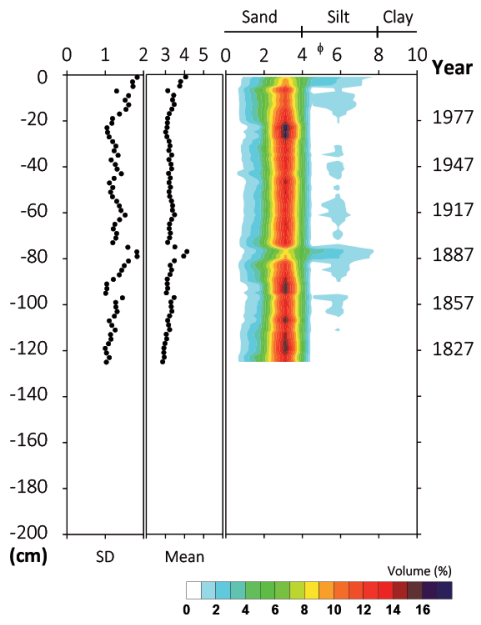

CANO7

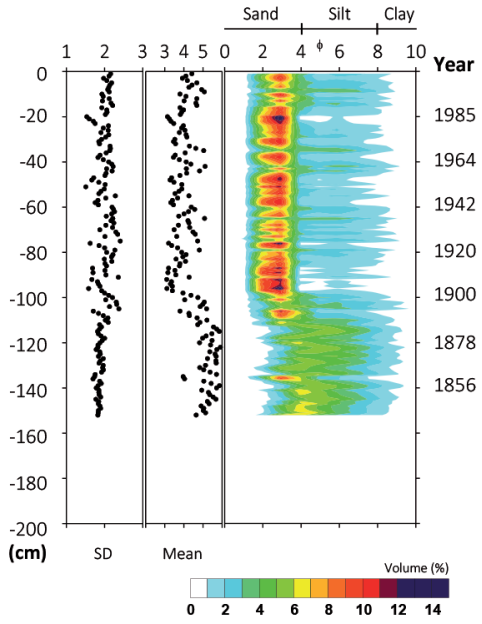

CANO4

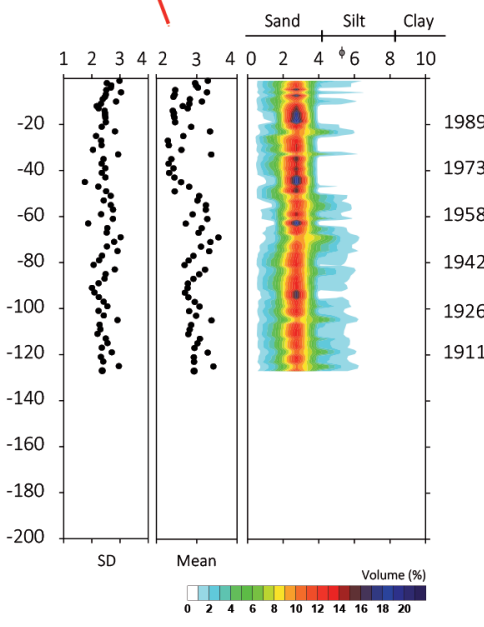

CAN15

Figure 5 - Particle Size Distributions (PSD) of the cores selected for this study. The methodology of the PSD is explained in Gyllencreutz (2005). 
et al. 2005) caused either by the construction of dams in the upstream or by a general trend of sea level rise over the last ca. 150 years. Therefore, it is important to observe the location of the delta feature inside an originally lagoonal environment that suffered dramatic changes over the last ca. 150 years and in which the influence of the opening of the artificial channel can be noted at great distances, resulting in either coastline changes (Tessler and Furtado 1983, Nascimento Jr. et al. 2008) or in vertical accumulation (Saito et al. 2001a, b).

\section{CONCLUSIONS}

In this paper, we report the origin and evolution of the Valo Grande delta, an anthropogenic intralagoonal delta that originated from the opening of an artificial channel called the Valo Grande.

The results indicate a progressive and severe progradation of the coastline and the colmatation of the area adjacent to the channel mouth and even the downstream sector of the channel itself. It was also possible to recognize the different facies of the deltaic environment and to estimate the sedimentation rates, which varied from 0.7 to more than $1.5 \mathrm{~cm} \mathrm{yr}^{-1}$.

The Valo Grande Delta represents an exception to the usual erosion trends in coastal deltas, caused either by the recent sea level rise or by the blockage of sediments to the coast in the last few centuries. Despite not being very frequent, anthropogenic deltas represent a favorable environment for the record of natural and anthropogenic changes in historical times and, thus, deserves more attention from researchers of different subjects.

\section{ACKNOWLEDGMENTS}

The authors are indebted to Mr. Clodoaldo Tolentino and Mr. Edilson Faria, for their help in the sampling survey and core sub-sampling. Financial support was provided by the Fundação de Amparo à Pesquisa do Estado de São Paulo (FAPESP), grant no. 06/04344-2.

\section{RESUMO}

O papel desempenhado pela atividade humana nas mudanças do litoral indica uma tendência geral de recuo da linha de costa, especialmente em ambientes deltaicos, como resultado da recente tendência de aumento do nível do mar, bem como do bloqueio do aporte de sedimentos em direção ao litoral, principalmente devido à construção de barragens. Isto é particularmente importante em ambientes deltaicos que sofreram uma perda dramática de área nas últimas décadas. Em contraste, no presente trabalho, relatamos a origem e evolução de um delta antropogênico, o Delta do Valo Grande, na costa sudeste do Brasil, cuja origem está relacionada com a abertura de um canal artificial e desvio do fluxo principal do rio Ribeira de Iguape. A metodologia incluiu a análise de mudanças de costa, levantamentos batimétricos e testemunhagem, esta última utilizada para determinar as taxas de sedimentação e mudanças na granulometria dos sedimentos ao longo do tempo. Os resultados permitiram reconhecer as diferentes facies do delta antropogênico e estabelecer suas tendências deposicionais, laterais e verticais. Apesar de não serem muito frequentes, deltas antropogênicos representam um ambiente favorável para o registro de mudanças naturais e antrópicas em tempos históricos e, portanto, merecem mais atenção dos pesquisadores de diferentes áreas do conhecimento.

Palavras-chave: atividade antrópica, Delta, sedimentação, laguna.

\section{REFERENCES}

Antonelli C, Provansal M and Vella C. 2004. Recent morphological channel changes in a deltaïc environment. The case of the Rhône River, France. Geomorphology 57: 385-402.

APPLEBY PG AND OLDFIELD F. 1978. The calculation of Lead210 dates assuming constant rate of supply $210 \mathrm{~Pb}$ to sediment. Catena 5:1-8.

BEIERLE BD, LAMOUREUX SF, COCKBURN JMH AND SPOONER I. 2002. A new method for visualizing sediment particle size distributions. J Paleolimnol 27: 279-283.

BONACHEA J ET AL. 2010. Natural and human forcing in recent geomorphic change; case studies in the Rio de la Plata basin. Sci Total Environ 408: 2674-2695.

COMMISSÃo GeOGRAPHICA E GEOLÓGICA DO Estado DE SÃo PAULO. 1914. Exploração do Rio Ribeira de Iguape. Rotschild, São Paulo. 
El BANNA MM AND FRIHY OE. 2009. Natural and anthropogenic influences in the northeastern coast of the Nile delta, Egypt. Environ Geol 57: 1593-1602.

FigueIRA RCL, TESSLER MG, MAHIQUES MM AND FuKUMOTO MM. 2007. Is there a technique for the determination of sedimentation rates based on calcium carbonate content? A comparative study on the Brazilian shelf. Soils Found 47: 649-656.

GAO S AND WANG YP. 2008. Changes in material fluxes from the Chanjiang River and their implications on the adjoining continental shelf ecosystem. Cont Shelf Res 28: 1490-1500.

GUILlÉN J AND PALANQUES A. 1997. A historical perspective of the morphological evolution in the lower Ebro delta. Environ Geol 30: 174-180.

GYLLENCREUTZ R. 2005. Late Glacial and Holocene paleoceanography in the Skagerrak from high-resolution grain size records. Palaeogeogr Palaeoclimatol Palaeoecol 222: 344-369.

GYLLENCREUTZ R, MAHIQUES MM, ALVES DPV AND WAINER IKC. 2010. Mid- to late-Holocene paleoceanographic changes on the southeastern Brazilian shelf based on grain size records. Holocene 20: 863-875.

IBGE. 1973. Topographical chart of Iguape. Scale 1:50,000. Brasil, Instituto Brasileiro de Geografia e Estatística.

ITALIANI DM AND MAHIQUES MM. 2014. O registro geológico da atividade antropogênica na Região do Valo Grande, estado de São Paulo, Brasil. Quatern Environ Geosci 5: $33-44$.

JAFFe BE, SMith RE AND Foxgrover AC. 2007. Anthropogenic influence on sedimentation and intertidal mudflat change in San Pablo Bay, California: 1856-1983. Est Coast Shelf Sci 73: 175-187.

JOSHI SR AND SHUKLA BS. 1991. AB initio derivations of formulation for ${ }^{210} \mathrm{~Pb}$ dating of sediments. J Radional Nucl Chemi 148:73-79.

Kapsimalis J, Poulos SE, Karageorgis AP, PaVlakis P AND COLLINS M. 2005. Recent evolution of a Mediterranean deltaic coastal zone: human impacts on the Inner Thermaikos Gulf, NW Aegean Sea. J Geol Soc 162: 897-908.

MahiQues MM, Burone L, Figueira RCL, LAVEnÉreWANDERley AAO, CAPEllari B, Rogacheski EC, BARroso CP, SANTOS ALS, CORDERO LM AND CUSSIOLI MC. 2009. Anthropogenic influences in a lagoonal environment: A multiproxy approach at the Valo Grande mouth, Cananéia-Iguape System (SE Brazil). Braz J Oceanogr 57: 325-337.
MARCHETTI M. 2002. Environmental changes in the central Po Plain (northern Italy) due to fluvial modifications and anthropogenic activities. Geomorphology 44: 361-373.

NASCIMENTO JR DR, GIANNINI PCF, TANAKAAPBAND GUEDES CCF. 2008. Mudanças morfológicas da extremidade NE da Ilha Comprida (SP) nos últimos dois séculos. Geologia USP Série Científica São Paulo 8: 25-39.

REN M. 1992. Human impact on coastal landform and sedimentation - The Yellow River example. GeoJournal 28: 443-448.

RESTREPO JD AND LÓPEZ SA. 2008. Morphodynamics of the Pacific and Caribbean deltas of Colombia, South America. Journal of South American Earth Science 25: 1-21.

Saito RT, Figueira RCL, Tessler MG AND Cunha IIL. 2001a. ${ }^{210} \mathrm{~Pb}$ and ${ }^{137} \mathrm{Cs}$ geochronologies in the CananeiaIguape Estuary (São Paulo, Brazil). J Radioanal Nucl Chem 249: 257-261.

SAito RT, FigueIRA RCL, TESSLER MG AND CUNHA IIL. 2001b. Geochronology of sediments in the CananeiaIguape estuary and in the continental shelf of São Paulo State, Brazil. J Radioanal Nucl Chem 250: 109-115.

Simeoni U AND Corbau C. 2009. A review of the Delta Po evolution (Italy) related to climatic changes and human impacts. Geomorphology 107: 64-71.

SYVITSKI ET AL. 2009. Sinking deltas due to human activities. Nature Geoscience 2: 681-686.

SYVITSKI JPM AND MILLIMAN JD. 2007. Geology, geography, and humans battle for dominance over the delivery of fluvial sediment to the coastal ocean. J Geol 115: 1-19.

SYVITSKI JPM AND SAITO Y. 2007. Morphodynamics of deltas under the influence of humans. Global Planet Change 57: 261-282.

SYVITSKI JPM, VÖRÖSMARTY CJ, KETTNER AJ AND GREEN P. 2005. Impact of humans on the flux of terrestrial sediment to the global coastal ocean. Science 308: 376-380.

TESSLER MGAND FURTADO VV. 1983. Dinâmica de sedimentação das feições de assoreamento da região lagunar CananéiaIguape, Estado de São Paulo. Boletim do Instituto Oceanográfico São Paulo 32: 117-124. 
